\title{
Adherence to diabetes medication among diabetic patients in the Bisha governorate of Saudi Arabia - a cross-sectional survey [Corrigendum]
}

\author{
Alqarni AM, Alrahbeni T, Al Qarni A, Al Qarni HM. Patient \\ Prefer Adherence. 2019;13:63-71.
}

On page 65, "Data collection" section, second paragraph, should read from "The MGLS was used to assess patient adherence to diabetic medications with permission from the scale owner. The composite four items in this adherence scale were: "Q1: Do you ever forget to take your diabetic medication?"; "Q2: Do you ever have problems remembering to take your diabetic medication?"; ..." to "The MGLS was used to assess patient adherence to diabetic medications which is in the public domain. The composite four items in this adherence scale were: "Q1: Do you ever forget to take your diabetic medication?"; "Q2: Are you careless at times about taking your diabetic medication?";..."
Patient Preference and Adherence is an international, peer-reviewed, open access journal that focuses on the growing importance of patient preference and adherence throughout the therapeutic continuum. Patient satisfaction, acceptability, quality of life, compliance, persistence and their role in developing new therapeutic modalities and compounds to optimize clinical outcomes for existing disease states are major areas of interest for the journal. This journal has been accepted for indexing on PubMed Central. The manuscript management system is completely online and includes a very quick and fair peer-review system, which is all easy to use. Visit http://www. dovepress.com/testimonials.php to read real quotes from published authors. 